\title{
Managing the supply of short-life products. A duration analysis approach using the UK film industry
}

Sofia Izquierdo-Sanchez ${ }^{*+}$

Department of Accountancy, Finance, and Economics. Research Centre for Productivity Improvement (RCPI). University of Huddersfield. HD1 3DH.

\begin{abstract}
Movies are uncertain products. Nobody knows much about them prior to their screening and their attempt to survive in the risky motion picture market week by week. This paper studies short-life products using the example of the UK film industry, including high and low-budget films. Using a clog-log methodology and a sample of 552 films, the empirical results highlight the importance of the distributor's strategy and word-of-mouth for success in experience goods industries. Two strategies, cross-subsidisation and opportunity cost, not previously addressed are considered. The results show these effects to be especially significant for low budget movies.
\end{abstract}

Keywords: short-life products; film industry; clog-log distribution; duration analysis

JEL classification: L21; D83

\section{Introduction}

Every week in the UK film industry more than 15 new films are released, and consumers can choose from more than 50 films to watch at the cinema, determining whether a film is sufficiently worthy to stay on screens for one more week. From the moment a film is released in theatres, its short life comprises of a competition for audience and box office revenues against films shown concurrently in cinemas. It is a hard competition for survival to stay on screens one more week in a market where box office revenues are mainly dominated by a few blockbusters, and where nobody knows anything about a film prior to watching it $^{1}$ (De Vany and Walls, 1999). Some films manage to stay in theatres for several weeks, while others

* Tel.: +44 (0) 148447 3018. E-mail: s.izquierdo-sanchez@ hud.ac.uk

+ I wish to thank Robert Simmons, Caroline Elliott, Colin Green, Maria Navarro Paniagua, Maurizzio Zanardi, Dakshina Da Silva, Bernd Frick, Joan Calzada Aymerich, and all the comments this paper received when it was presented in conferences. Any errors of course remain the responsibility of the author.

1 Some films are released in the US earlier than in the UK, so in the case of the UK film industry potential viewers already have information about some of the films. 
seemingly leave the screens quite soon. This article studies the supply side of competition in experience goods markets, using the UK film industry as an example.

Some products released in the market are short-life products that meet the characteristics of event data and a day by day fight to survive in the market until they disappear. These products start by having high, rapidly growing sales, following a consistent pattern of strong growth during a certain period of time, which then reverses and starts to decline until the product is out of the market, giving way to new products (Golder and Tellis, 2004); this process can last for years, months, or weeks and is applicable to films. Films are uncertain products, with only partial information available about them prior to their release in cinemas. The special characteristics of films ${ }^{2}$ is that their life is very short compared to other types of products; i.e. films' sales grow and decline very quickly, and distributors have to know how to react quickly to shocks in demand. This underscores the importance of studying the determinants of films' life on screens. These determinants have already been researched in several studies, mostly in the US (Albert, 1999; De Vany and Walls, 1996, 1997 and 1999; Deuchart et al., 2005; Nelson et al., 2001; Prag and Cassavant, 1994; Sedgwick and Pokorny, 1998; Smith and Smith, 1986; Walls and McKenzie, 2012).

Most of these studies focus on successful films released in the US market ${ }^{3}$, trying to predict the probability of a film's success and also whether a film will continue its run the following week. Meanwhile, the current study uses a duration analysis to examine the UK film industry market which includes successful and unsuccessful films, and distributor strategies not previously taken into account in the empirical film industry literature, such as the crosssubsidisation between large blockbusters and smaller releases from the same distributor, the opportunity cost of keeping a film on screens given the success of the other concurrently shown films, and the impact of word-of-mouth. The analysis of duration is important in the film industry, as the decision of producers and theatres to increase or decrease the length of the run is the most common method of adjusting supply to demand, and these decisions have to be made rapidly given the short life of films on screens. However, the conclusions could be extended to other experience goods markets, such as textiles, DVDs, CDs, or restaurants, i.e. goods whose quality cannot be determined prior to purchase (Nelson, 1970).

2 This article only considers films while they are being shown in cinemas; however, other avenues of distribution can also be considered, such as Netflix or DVD.

${ }^{3}$ This is mainly due to the lack of public data available. However we can find some studies which also include low budget movies (see for example: Sedgwick and Pokorny, 1998). 
The paper is structured as follows: the next Section summarises the related literature; Section 3 briefly explains the UK film industry; Section 4 explains the data and methodology used; Section 5 presents the main results; and conclusions are presented in Section 6.

\section{Literature review}

Since 1986, not only have the characteristics of films changed (Smith and Smith, 1986), but consumers' preferences and interests as well. A free and increasingly used marketing tool is word-of-mouth, and, nowadays, internet, newspapers, TV, radio, and social networks allow consumers to spread information more quickly, making it necessary to include additional variables, such as expert critics or word-of-mouth, in the analysis of the determinants of the life of films on screens.

De Vany and Walls (1997) use a sample obtained from Variety of 350 high-grossing films between 1985 and 1986 to study the shape of the hazard rate and survival functions in the film industry. They show that both the hazard rate and survivor functions are time-dependent, and that the information transmission among viewers is via word-of-mouth, finding that, in the case of the film industry, it is appropriate to use a Weibull distribution. Walls (1998) replicated these results for the Hong-Kong market, and Walls (2009) examines the survival of movies on screens in the Thailand movie market.

The results using this distribution from De Vany and Walls (1997) show that a wide release cannot guarantee high revenues after the early weeks, and that each of the characteristics of a film considered, such as initial number of screens, box office revenues, period of release, rank of the film in a week given by Variety, and number of weeks in the current release period, affect the survival time conditional on the other characteristics. In a later study, De Vany and Walls (1999) use quantile regressions to examine the conditional probability that a film will continue to earn high revenues given past earnings, and show that this probability declines.

In a more recent study, Nelson et al. (2001) illustrate the positive impact of Oscar awards and nominations on survival time using a sample of 131 films between 1978 and 1987. They obtained data from Variety for the top 50 grossing films. First, the authors estimate two different models, where total number of screens and average revenues per screen are the dependent variables, using a linear and a log-linear functional form, respectively, and consider different variables' specifications and interactions in each one. Secondly, they 
determine the value of OSCAR awards and nominations to the films' probability of survival and its increase in length of run for one more week. Following De Vany and Walls (1997), they use a Weibull distribution allowing for duration dependence and the incorporation of covariates. They also support the idea of De Vany and Walls (1997) that survival time is strongly related to the number of initial bookings and the month in which a film is released.

Deuchart et al. (2005) argue that Oscar nominations have positive effects on box office revenues, as they can be used as a sign of quality by potential audiences. Replicating the results of Nelson et al. (2001) with recent data, they use a Weibull distribution to examine the time interval from the first week of release until the film is taken out of distribution. The authors use a total sample of 2,244 high-ranked films released in the US from January 1990 to December 2000; the weekly rank of the film was obtained from Variety's database. They conclude that nominations increase the running time of films on screens from the moment they are revealed to viewers, and not just from the time awards are granted, as argued in previous papers.

Finally, Chisholm and Norman (2006) study the probability of a film's exit from the market using a log-logistic and Weibull specification, following Greenstein and Wade (1998). The authors show that the decision to drop a film is mainly affected by its ranking compared to other films showing concurrently at the theatre.

\section{The UK film industry market}

Once a film is produced, the distributor chooses the release pattern in order to maximize profits from the film and cover all the production costs. The opening dates are jointly negotiated between distributors and exhibitors, seeking higher demand periods and trying to avoid competing against films that are strong substitutes. According to the early estimates of demand, exhibitors decide on the number of screens and locations of initial theatres, with the maximum initial period for the distributor and exhibitor to contract a film's opening release in the UK being two weeks (Ofcom, 2007). This period of time varies per country, for example in the US the distributor-exhibitor contract typically requires the cinema to show the movie for a minimum number of weeks, in this case the most common minimum number of weeks is 4 weeks, although 6 and 8 weeks are also sometimes negotiated (De Vany and Walls, 1996). Similarly to the US, normally, the exhibition license includes a clause that specifies a threshold box office revenue in the early weeks of the contracted run ("House 
Nut" model), and that triggers the run to be extended for one more week ${ }^{4}$. Distributors use the information provided by box office reports to adjust the release pattern dynamically so as to match supply to demand, the split typically changes over time. Due to the relative high cost of media advertising and the historic deals between UK cinemas and distributors, in the UK it can be found some of the highest exhibitor splits in the world. The different stages of the film industry supply chain and the interaction between the agents involved, offer many opportunities for future research (McKenzie, 2012).

The UK film industry contributed over $£ 4.6$ billion to British GDP in 2011 , paid over $£ 1.3$ billion to the Exchequer in tax revenues, and supported a total of about 100,000 jobs (Oxford Economics, 2012). It also enhances the economy and Exchequer by promoting British cultural life and addressing the social challenges of the 21st century. Table 1 summarizes the contribution to the British economy of the UK film industry in 2009.

Table 1 around here

Stimulating the demand for the UK film industry is beneficial for the UK economy, especially in the last years that consumer spending has been constrained due to the worldwide economic crisis. Despite the last recession, the Oxford Economics 2012 report demonstrates that the UK film industry is thriving. With a significant upward trajectory over the last 20 years, the overall picture of the UK film industry is that of continuing long-term growth. This growth in cinema attendance can be associated with changes in cultural preferences, the increase in incomes, new technology, digital cinema screens and 3D screens, and increases in films' advertising expenditure, which stimulates word-of-mouth and thus affects cinema attendance.

\section{The empirical duration model}

A dataset has been created for this paper providing recent data for a broad range of variables. Weekly data was collected for approximately one year, from May 2011 to June 2012, for every film released in UK cinemas - a total of 552 films $^{5}$. Many variables have been collected

\footnotetext{
4 This practise could vary depending on the agreement. Another common practise is to split the ticket income after VAT (UK sales tax) is removed. More information can be found at: https://stephenfollows.com/how-a-cinemas-box-office-income-is-distributed/

5 During the first week, only information for those films released during that week was collected. In May 2011 no more information about new films was collected and the data collection ended when the last movie from the dataset was removed from the screens, i.e. for every movie there is data from the release week until it is removed from the screens.
} 
for each film, including users' number of votes and expert critics' scores (word of mouth effect), director, popular actors/actresses, OSCAR academy award and BAFTAs prizes and nominations, genre, distributor, British Board of Film Classification (BBFC), budget, advertising expenditure, and box office revenues ${ }^{6}$. The descriptive statistics and a description of the variables are provided in Appendix A (Table A.1 and A.2).

Each film in the sample was tracked from its birth until its death. Birth is defined as the moment the film is released on screens, and death is defined as its removal from theatres. The 552 films in the sample are divided into two groups: high and low budget films. Nowadays, it is increasingly common to consider a film as a blockbuster, or of great commercial success, if the budget spent on its production is high. This is the case for films such as Harry Potter and The Lord of the Rings. A high budget can be used by potential viewers as a sign of a film's high quality. Observing the distribution of the films' production budget in the sample (Figure 1), films are divided exactly in the mean point depending on the budget ${ }^{7}$. So a boundary of a 44.7 (million \$) budget will distinguish between high and low budget films. However, budget is a difficult variable to collect data for, as studios are reluctant to share specific information due to contractual and financial reasons. As a high budget implies more money spent on salaries, advertising, and promotion, a popular cast will be used as a proxy for high budget films for those films where production budget data was not available ${ }^{8}$.

The distribution of the length of run is presented in Table 2. The maximum length of run is 28 weeks for the film Tinker, Tailor, Soldier, Spy, and the minimum length of run is one week, to which several films, such as Stormhouse, Sweet Little Lies, and Evil Things, pertain. Box office revenues and advertising, in general, start out low and increase in the middle of the film's life, declining again towards the end. However, expert critics and users' ratings follow a constant, increasing trend, which can give a preliminary indication of a film's survival prospects, whereby, in average, films that receive positive expert and users' reviews survive longer than films that receive negative reviews.

Figure 1 around here

\footnotetext{
${ }^{6}$ Different sources have been used to collect the data: British Film Institute (BFI), IMDb, Box Office Mojo, and different UK newspapers (more information available in Appendix A, Table A.1). Advertising expenditure data was obtained from Nielsen UK.

7 Results have also been tested for different division possibilities around the value selected. These results are robust and are available upon request.

${ }^{8}$ Both analysis, including the proxy and without the proxy are presented, testing the robustness of the results (Table 4).
} 
Table 2 around here

The main reason for using duration models in the film industry is to explain the way in which supply continuously adjusts to demand during a film's run. The decision of producers and theatres to increase or truncate the length of the run will depend on several external factors that may affect consumers, and so the decisions of producers and exhibitors will be affected weekly by demand. De Vany and Walls (1997) and Nelson et al. (2001) argue that the hazard rate increases over time and that the survivor functions are time-dependent in the case of the film industry, so it is appropriate to use a Weibull distribution. However, this distribution assumes an increasing hazard function; as a consequence this paper considers an alternative methodology, not making preliminary assumptions related to the shape of the hazard function to study the determinants of the screen-life of films.

Distributors face important decisions during the life of a movie on screen. Once a film is produced, the distributor chooses the release pattern in order to maximize profits from the film and cover all the production costs. The release date is one of the first and main decisions by which studios compete with each other (Chisholm and Norman, 2006; Einav and Ravid, 2009; Einav, 2010). Prices play a very small role in the distributor's decisions, as they are identical or very similar among exhibitors in the UK; other attributes to consider will be content, advertising, and time (De Vany and Walls, 1996). Other industries where competition centres on time instead of prices are books, compact discs, television programs, and so on (some example are: Goetter and Shachar, 2001; Sweeting, 2009). This paper distinguishes between four important factors that the distributors have to consider when deciding to release a film and/or keep a film on screens for one more week: the release date, the cross-subsidisation between large blockbusters and smaller releases from the same distributor, the opportunity cost of keeping a film on screens given the success of other similar concurrently showing films, and the impact of word-of-mouth'.

The life of a film on screens can be defined as the interval from birth to death, considering that the number of screens available decreases over time (Table 2). Distributors will decide to keep a movie on screens during a certain period of time $(\boldsymbol{\alpha})$. This interval is a random variable $\alpha$ with distribution function $F(t, X)=\operatorname{Prob}(\alpha \leq t)$, where $X$ represents a set of individual characteristics of each film and $t$ represents the weekly length of run. The survival

9 From now onwards, this papers assumes that viewers watch a maximum of one film per week. 
function is defined as the probability that a film is still shown on theatres at week $t$ : $S(t, X)=1-F(t, X)=\operatorname{Prob}(\boldsymbol{\alpha}>t)$. In the case of the film industry, duration analysis considers the conditional probability that a film will continue on screens, given that it already has been in theatres for a certain period of time. This is known as the hazard rate, that is the instantaneous rate of failure for each time, and it is defined as: $h(t, X)=f(\alpha \mid \alpha \geq t)=-\frac{s(t, X)}{s(t, X)}$ where $s(t, X)$ is the density of the survival function ${ }^{10}$. The hazard rate is a function of time and can increase, decrease, or remain constant with time.

As explained previously, two types of films are included in the dataset: high and low budget films. The baseline survivor function for these groups is estimated and they are then tested for equality using the log-rank test. The log-rank test examines the null hypothesis whereby there is no difference between the two groups (successful and unsuccessful films) in the probability of death at any time. The results of the test are presented in Table 3. Taking into account that the probability that the t-statistic is greater than the chi-squared test statistics is 0.0000 , the null hypothesis can be rejected at conventional significance levels, and so observations for high and low budget films should not be pooled.

\section{Table 3 around here}

Figure 2 plots the product-limit estimate for the sample divided by high budget and low budget films. The Kaplan-Meier survival curve is a maximum likelihood estimator and is defined as the probability of surviving a given length of time, while considering time in many small intervals (Kaplan and Meier, 1958). The estimated survivor functions are decreasing, implying that, after birth, all films tend to die at some point. High budget films have a greater probability of surviving during the first weeks than low budget films. However, it can be observed that, from week 20, the probability of surviving is greater for low production budget films than it is for high budget films. This is an interesting result, an explanation for which can be offered if we take into consideration the effects that advertising and word-of-mouth have on film duration. In the entertainment industry jargon, "sleepers" is a term for a film that plays successfully for a long period of time and becomes a big success despite having only little promotion or a successful opening. For example, the film Tinker, Tailor, Soldier,

10 The hazard rate is normally defined as $\frac{f(t, x)}{s(t, X)}$ where $f(t)$ is the density function of $F(t, X)$, however a survival density function can be described as $s(t, X)=S^{\prime}(t, X)=\frac{d}{d t}[1-F(t, X)]=-f(t, X)$. 
Spy is a low budget ( $£ 20$ millions) film included in our dataset, which unexpectedly managed to last for 28 weeks; it does have some big name actors in it, which can give potential audiences a preliminary idea of the film's quality.

Figure 2 around here

Figure 3 shows the maximum likelihood estimate of the hazard function to check the time dependence of the hazard rate (Kalbfleisch and Prentice, 1980). The plot indicates an increasing time dependence of the hazard rate for both high and low budget films, and is thus, as some authors have argued before in the case of the film industry, appropriate when considering non-constant hazard rate distributions; one of these distributions is the Weibull distribution (De Vany and Walls, 1997; Nelson et al., 2001). However, this paper will consider the cloglog distribution, which doesn't assume any specific hazard shape. Time process is described in discrete time instead of continuous time.

Prentice and Gloeckler (1978) and Jenkins (1995) show that the discrete time counterpart of an underlying continuous time proportional hazard model is a complementary log-log function called cloglog, which means that the resulting hazard is the following: $h(t, X)=1-\exp \left[-\exp \left(h_{0}(t)+\beta^{\prime} X\right]\right.$ where $h_{0}(t)$ is the baseline hazard and $\exp \left(\beta^{\prime} X\right)$ is

a non-negative function of the covariates assumed to be an exponential function in the standard literature. Taking logs: $\log [-\log (1-h(t, X))]=h_{0}(t)+\beta^{\prime} X{ }^{11}$

Figure 3 around here

\section{Empirical results}

This paper includes a broad range of explanatory variables to study the determinants of high and low budget films' lives. Two new strategies are considered: the cross-subsidisation between large blockbusters and smaller releases, and the opportunity cost of keeping a film on screens for one more week given the success of concurrently showing films. Previous studies have shown that the exhibitors' strategy in order to keep the movie on screens one more week will be influenced by similar films played at the theatre during the same week

\footnotetext{
11 The dataset is organised according to the discrete time proportional hazard model defined by Prentice and Gloecker (1978). There is one observation for each period when a movie (subject) is at risk of experiencing the transition event (one more week on screens). The resulting dataset has the same form than a discrete panel dataset with repeated observations on each subject.
} 
(opportunity cost) and the other films played at the same time by the same distributor (crosssubsidisation).

Chisolm and Norman (2006) define the variable "RANKATTHEATER" as the revenues of a film relative to the other films playing at the theatre at the same week, however this paper considers that the competition between films depends on the target audience; for example Bridesmaids targets a different type of audience than Paranormal Activity, however it will target similar audience to other romantic comedy films and so the competition level between Bridesmaids and other romantic comedy films will be higher than against Paranormal Activity. In order to account for this effect, this paper defines opportunity cost as the total box office revenues of all films of similar genre played in one week, minus the box office revenues of a particular film in that week. Different film genres can target similar types of audiences. Based on previous studies by Redfern (2012) and BFI/Northen Alliance/Ipsos Media CT (July 2011), films have been divided in four genre groups depending on the most likely target audience: Genre group 1 (females under 45): Family, romance, and romantic comedies. Genre group 2 (females over 45): Drama and musical. Genre group 3 (males under 45): Horror, fantasy, comedy, animation, sci-fi, action, adventure, and movies based on comic/book. Genre group 4 (males over 45): Documentary, thriller, and suspense. ${ }^{12}$ For examples, the total box office revenues in week 9 of the films belonging to "genre group 3" is $£ 142,000,000$, and the opportunity cost of keeping Horrible Bosses (it being the $8^{\text {th }}$ week of this film on screens) for one more week, given that similar genre films which target a similar audience such as The Tree of Life (it being the $10^{\text {th }}$ week of this film on screens) or The Beaver (it being the $4^{\text {th }}$ week of this film on screens) are being concurrently shown, is $£ 44,300,000$ ( $£ 142,000,000$ - the box office revenues that Horrible Bosses produced in week 9).

Another strategy that the distributors can follow is the cross-subsidisation between high and low production budget movies. Low production budget movies could be good examples of slow burners or sleepers and so the agents could decide to keep one week more a low production budget on screens while subsidising it with the revenues coming from their other own movies played during that same week, while waiting for the film to generate profits. The

12 A film can be classified with more than one genre, if for example film $i$ is classified as family and adventure, it will be taken into account in both Genre group 1 and Genre group 3. As according to the "target audience" assumption this film will be a potential substitute for other films classified as family and/or adventure. 
maximum number of films in the dataset shown by the same distributor in one week is 6 , appearing at week 25 (Universal Studios), week 26 (Universal Studios), week 27 (Universal Studios), week 36 (Entertainment Film Distributors), and week 41 (20 ${ }^{\text {th }}$ Century Fox). The cross-subsidisation variable is defined as the total box office revenues of all films played in one week by distributor $j$, minus the box office revenues of a particular film $(i)$ in that week distributed by $j$.

As mentioned in Section 4, and following the graphical results from Figure 2 and 3. This paper considers a clog-log function methodology broadly used in the labour and health economics literature (some examples are: Nordman and Pasquier-Domer, 2014; Mortelmans and Vannieuwenhuyze, 2013). Results are presented in table $4^{13}$.

Table 4 around here

Some interesting results can be found: users' number of weekly votes, expert critics and weekly advertising expenditure are statistically significant for high budget films; both increase the probability of surviving. This trend indicates that filmgoers are more likely to watch high budget films when they receive positive reviews and the advertising expenditure is large. Therefore, positive expert review scores, users' number of votes, and a large advertising expenditure will encourage audiences to see these films, giving rise to potentially very large initial box office revenues (Table 5).

The increase in box office revenues increases the probability of surviving the following week for low budget films. Box office revenues are also related to people's opinion or the word of mouth effect. Indeed, some authors argue that herd behaviour and/or information cascades can be found when studying the correlation between weekly box office revenues (De Vany and Walls, 1996; Walls, 1998). In the case of low budget films, there are not many signs of quality provided by the producing company, so filmgoers have to rely on other possible signs of quality such as the box office revenues, which can be used as a proxy for public opinion and thus affect cinema attendance. Another variables that are an indicator of quality are OSCAR/BAFTA nominations, popular cast, and UK expert critics (Deuchert et al., 2005; Elliott and Simmons, 2008; Nelson, 2001). Hence, films that receive positive expert reviews or OSCAR/BAFTA prizes or nominations (note that the coefficient for $U K$ expert critics,

${ }^{13}$ The distributor selects the films to be exhibited in each geographic market (Walls and McKenzie, 2012). However, this paper does not control for this selection bias on the part of the distributor. 
popular cast and OSCAR/BAFTA prizes or nominations are statistically significant for low budget films) may became successful ("slow burners").

This paper empirically studies the effect on experience goods of the cross-subsidisation between films released by the same distributor, and the opportunity cost of keeping a film on screens for one more week given the success of the other films, which target a similar audience, that are concurrently shown. The coefficients for both the opportunity-cost and cross-subsidisation are statistically significant for low budget films, decreasing the probability of surviving the following week. In the case of the cross-subsidisation coefficient, this means that the probability of surviving and staying on screens for one more week for low budget films decreases if the total box office revenues of the rest of the films shown by the same distributor in a given week increases compared to the box office revenues of a given low production budget movie, i.e. the higher the level of cross-subsidisation the higher the probability of removing a specific movie from screens. This effect together with the total box office revenues and the word of mouth effect for a specific movie shows that the distributor will consider to continue subsidising the film with large blockbusters if a specific low budget film shows some potential to increase revenues in the following weeks, and so the crosssubsidisation strategy will not be needed in the near future for that given film.

The maximum number of films shown by the same distributor in one week is 6. For example, in week 25 of the dataset Universal Studios was showing two high budget films on screens, Immortals and Tower Heist, and four low budget films, Jane Eyre, Johnny English Returns, One Day, and The Debt; these last four films remained on screens 12, 18, 14, and 11 weeks, respectively, a similar number of weeks that the high budget films lasted. Looking at different examples in different weeks, low budget films that have a successful life share similar characteristics; they receive positive expert scores that encourage potential consumers to see the films, thus increasing box office revenues and, during their lifetime, the distributor keeps releasing high budget films that will have huge initial box office revenues, indicating that high budget films subsidise smaller releases from the same distributor.

In the case of the opportunity-cost coefficient, it is positive and statistically significant for low budget films. This means that the higher the difference between the total box office revenues of all films played along with a similar target audience objective in one week minus the box office revenues of a particular film in that week, the higher the probability is for a film to be taken off the screens, this effect is particularly important in the case of low 
production budget films; i.e. distributors will decide to remove a film from screens if the box office revenues that a film is producing is small compared to the box office revenues produced by other films which target a similar audience and which are shown concurrently. These results are in line with those found by Chisolm and Norman (2006), although they considered the performance of a film compared to all the other films shown on screens during the same period of time without distinguishing by target audience groups.

Table 5 around here

\section{Conclusions}

Weekly data for every film released in the UK during one year was used to provide empirical evidence about duration analysis in the film industry. Two commonly used strategies but not considered before in the experience goods empirical film industry literature are investigated here: the cross-subsidisation between films released by the same distributor, and the opportunity cost of keeping a film on screens for one more week given the success of other films with similar genre shown concurrently. This paper shows that the determinants of the life of films on screens are different for low and high budget films, highlighting the importance of considering a wide sample of films and range of variables in future research.

Low and high budget films are included together with a large number of explanatory variables to determine the probability of films surviving on screens. Moreover, this paper considers an alternative methodology to that used in past papers to study the duration of experience goods. The clog-log distribution does not assume any particular shape of the hazard rate, and thus allows consideration of time varying covariates. This research studies the optimal distributors' strategy, highlighting the importance of box office revenues and expert critics affecting word-of-mouth and increasing cinema attendance. These results indicate the importance of studying advertising expenditure and box office revenues in a subsequent study for experience goods industries, examining the determinants of these endogenous variables using a simultaneous equation system. 


\section{Appendix A}

Table A.1: Description of the variables

\begin{tabular}{|c|c|c|}
\hline Variable & Description & Definition \\
\hline Cross-subsidisation & $\begin{array}{l}\text { Total box office revenues by week } \\
\text { and distributor minus the box office } \\
\text { revenues of each film by a given } \\
\text { distributor in a week. }\end{array}$ & $\begin{array}{l}\text { Cross-subsidisation between } \\
\text { large blockbusters and } \\
\text { smaller releases from the } \\
\text { same distributor }\end{array}$ \\
\hline Opportunity cost & $\begin{array}{l}\text { Total box office revenues by week of } \\
\text { the same genre films (which target a } \\
\text { similar audience) minus the box office } \\
\text { revenues of each film in a week. }\end{array}$ & $\begin{array}{l}\text { Opportunity cost of keeping } \\
\text { a film on screens for one } \\
\text { more week given the success } \\
\text { of the other films that are } \\
\text { shown concurrently. }\end{array}$ \\
\hline Users' number of votes & Weekly number of votes by film & $\begin{array}{l}\text { females/males under } 18 ; \\
\text { between } 18-29 \text {; between } 30 \text { - } \\
44 \text { and older than } 45\end{array}$ \\
\hline UK Expert critics & $\begin{array}{l}\text { Weekly UK Expert critics average } \\
\text { scores }\end{array}$ & $\begin{array}{l}\text { Newspapers: The Guardian, } \\
\text { Daily Express, Daily Mail, } \\
\text { Daily Mirror, Daily } \\
\text { Telegraph, The Independent, } \\
\text { The Times, The Sun, and the } \\
\text { expert critics presented in the } \\
\text { web pages Yahoo! IMDb } \\
\text { staff. }\end{array}$ \\
\hline Prizes and nominations & $\begin{array}{l}1=\text { the film was nominated or won an } \\
\text { OSCAR/BAFTA; } 0=\text { otherwise }\end{array}$ & $\begin{array}{l}\text { OSCAR/BAFTA nomination } \\
\text { categories 2011/2012 }\end{array}$ \\
\hline Popular cast & $\begin{array}{l}1=\text { Oscar or BAFTA winner } \\
\text { nomination in the last } 5 \text { years, } \\
0=\text { otherwise }\end{array}$ & $\begin{array}{l}\text { Actor/actress that has been } \\
\text { nominated to an Oscar or } \\
\text { BAFTA in the last } 5 \text { years }\end{array}$ \\
\hline Box office UK & $\begin{array}{l}\text { Weekly box office Revenues in the } \\
\text { UK }(£)\end{array}$ & \\
\hline Advertising expenditure & Weekly advertising expenditure $(£)$ & \\
\hline Genre & $\begin{array}{l}1=\text { if a film is classified as comedy, } \\
\text { war, action...; } 0=\text { otherwise. }\end{array}$ & \\
\hline Book/Sequel & $\begin{array}{l}1=\text { Original idea of the movies comes } \\
\text { from a book or comic. Or the movie } \\
\text { is a sequel; } 0=\text { otherwise }\end{array}$ & \\
\hline BBFC under 18 & $\begin{array}{l}1=\text { if BBFC (British Board of Film } \\
\text { Classification) is General Public (PG) } \\
\text { or Universal (U); } 0=\text { Otherwise }\end{array}$ & \\
\hline Major distributor & $\begin{array}{l}1=\text { the distributor and producer is one } \\
\text { of the "Big } 6 " ; 0=\text { otherwise }\end{array}$ & \\
\hline Seasonal effects & $\log ($ week $)$ & $\begin{array}{l}\text { The variable week indicates } \\
\text { the week of the year the film } \\
\text { has been released }\end{array}$ \\
\hline
\end{tabular}


Table A.2: Descriptive statistics

\begin{tabular}{lcccc}
\hline Variable & Mean & Std. Dev. & Min & Max \\
\hline Cross-subsidisation & $19,400,000$ & $34,700,000$ & 0 & $218,000,000$ \\
Opportunity cost & $93,200,000$ & $107,000,000$ & 0 & $464,000,000$ \\
Expert critics & 6.03 & 1.761 & 2 & 10 \\
Oscar/BAFTA prizes and nominations 2012 & 0.073 & 0.26 & 0 & 1 \\
Popular cast & 0.156 & 0.363 & 0 & 1 \\
Number of votes & $15,442.22$ & 36,750 & 0 & 385,084 \\
Weekly box office revenues & $3,448,379$ & $8,463,557$ & 0 & $140,000,000$ \\
Weekly advertising expenditure & $8,385.5$ & $45,842.54$ & 0 & 906,096 \\
Action & 0.1744 & 0.3795 & 0 & 1 \\
Adventure & 0.0756 & 0.2644 & 0 & 1 \\
Sci-fi & 0.0617 & 0.2406 & 0 & 1 \\
Comedy & 0.2716 & 0.4448 & 0 & 1 \\
Family & 0.0525 & 0.2231 & 0 & 1 \\
Animation & 0.0645 & 0.2458 & 0 & 1 \\
Romance & 0.1364 & 0.3433 & 0 & 1 \\
History & 0.0202 & 0.1409 & 0 & 1 \\
Crime & 0.0506 & 0.2193 & 0 & 1 \\
Horror & 0.0588 & 0.2354 & 0 & 1 \\
Thriller & 0.1769 & 0.3816 & 0 & 1 \\
Drama & 0.1766 & 0.3814 & 0 & 1 \\
Book & 0.0172 & 0.1303 & 0 & 1 \\
Sequel & 0.0336 & 0.1803 & 0 & 1 \\
Major distributor & 0.1603 & 0.3696 & 0 & 1 \\
BBFC under 18 & 0.9276 & 0.2590 & 0 & 1 \\
\hline
\end{tabular}




\section{References}

Albert, S. (1999). "Movie Stars and the Distribution of Financially Successful Films in the Motion Picture Industry”, Journal of Cultural Economics, 22(4): 249-270.

BFI/Northen Alliance/Ipsos Media CT. (July 2011). "Opening our Eyes: How Film Contributes to the Culture of the UK", URL: http://www.bfi.org.uk/about-bfi/policy$\underline{\text { strategy/opening-our-eyes-how-film-contributes-culture- } \mathrm{uk}}$

Chisholm, Darlene C., and Norman, G. (2006). "When to Exit a Product: Evidence from the U. S. Motion-Picture Exhibition Market", American Economic Review, 96(2): 57-61.

De Vany, A. and Walls, W. D. (1996). "Bose-Einstein Dynamics and Adaptive Contracting in the Motion Picture Industry", Economic Journal, 106(439): 1493-1514.

De Vany, A. and Walls, W. D. (1997). "The Market for Motion Pictures: Rank, Revenue and Survival", Economic Inquiry, 35(4): 783-797.

De Vany, A. and Walls, W. D. (1999). 'Uncertainty in the Movie Industry: Does Star Power Reduce the Terror of the Box Office?", Journal of Cultural Economics, 23(4): 285318.

Deuchert, E., Adjamah, K. and Pauly, F. (2005). 'For Oscar Glory or Oscar Money?", Journal of Cultural Economics, 29(3): 159-176.

Einav, L. and Ravid, S.A. (2009). "Stock Market Response to Changes in Movies' Opening Dates", Journal of Cultural Economics, 29(3): 177-190.

Einav, L. (2010). "Not All Rivals Look Alike: Estimating an Equilibrium Model of the Release Date Timing Game", Economic Inquiry, 48(2): 311-319.

Elliott, C., and Simmons, R. (2008). Determinants of UK Box Office Success: The Impact of Quality Signals, Review of Industrial Organization, 33(2): 93-111.

Golder, P. N. and Tellis, G. J. (2004). "Going, Going, Gone: Cascades, Diffusion, and Turning Points of the Product Life Cycle", Marketing Science, 23(2): 207-218.

Goettler, R. L., and Shachar. R. (2001). "Spatial Competition in the Network Television Industry", RAND Journal of Economics, 32(4): 624-56.

Greenstein, S. M. and Wade, J. B. (1998). "The Product Life Cycle in the Commercial Mainframe Computer Market, 1968-1982.” RAND Journal of Economics, 29(4): 77289. 
Jenkins, S.P. (1995). "Easy Estimation Methods for Discrete-Time Duration Models", Oxford Bulleting of Economics and Statistics, 51(1): 129-138.

Kalbfleisch, J.D. and Prentice, R. L. (1980). "The Statistical Analysis of Failure Time Data", Wiley Series in probability and statistics.

Kaplan, E. L. and Meier, P. (1958). "Nonparametric Estimation from Incomplete Observations", Journal of the American Statistical Association, 53(282), 457-481.

McKenzie, J. (2012). "The Economics of Movies: A Literature Survey”, Journal of Economic Surveys, 26(1): 42-70.

Mortelmans, D., and Vannieuwenhuyze, J. T. A. (2013). "The Age Dependent Influence on Self-Reported Health and Job Characteristics on Retirement", International Journal of Public Health, 51(8): 13-22.

Nelson, P. (1970). 'Information and Consumer Behavior", Journal of Political Economy, 78(2): 311-329

Nelson, Randy A; Donihue, M. R; Waldman, D. M.; and Wheaton, C. (2001). "What's an Oscar Worth?", Economic Inquiry, 39 (1): 1-16.

Nordman, C. J., and Pasquier-Doumer, L. (2014). "Transitions in a West African Labour Market: The Role of Family Networks", IZA DP, No 8349.

Ofcom (2007). "Movie Markets in the UK", Annex 11 to pay TV market investigation consultation.

Oxford Economics. (September, 2012). "The economic impact of the UK film industry", report supported by the BFI, Pinewood Shepperton plc, British film commission and Creative England.

Prag, J. and Cassavant, J. (1994). "An Empirical Study of Determinants of Revenues and Marketing Expenditures on the Motion Picture Industry", Journal of Cultural Economics, 18(3): 217-235.

Prentice, R. L. and Gloeckler, L. A. (1978). "Regression Analysis of Grouped Survival Data with Application to Breast Cancer Data", Biometrics, 34(1): 57-67.

Redfern, N. (2012). "Correspondence Analysis of Genre Preferences in the UK Film Audiences", Journal of Audience and Reception Studies, 9(2): 45-55.

Sedqwick, J; and Pokorny, M. (1998). "The Risk Environment of Film Making: Warner Bros in the Inter-War Years", Explorations in Economic History, 35(2): 196-220.

Smith, S. P. and Smith, V. K. (1986). "Successful Movies: A preliminary Empirical Analysis", Applied Economics, 18(5): 501-507. 
Sweeting, A. (2009). "The Strategic Timing of Radio Commercials: An Empirical Analysis Using Multiple Equilibria”, RAND Journal of Economics, 40(4): 710-742.

Walls, W. D. (1998). "Product survival at the cinema: Evidence from Hong-Kong", Applied Economic Letters, 5(4), 215-219

Walls, W. D. (2009). "The market for motion pictures in Thailand: Rank, revenue, and survival at the box office." International Journal of Business and Economics, 8(2): $115-131$

Walls, W. D. and McKenzie, J. (2012). "The changing role of Hollywood in the global movie market." Journal of Media Economics, 25(4): 198-219 
Table 1: Summary of the economic contribution of the UK film industry

\begin{tabular}{lccc}
\hline Channel of impact & $\begin{array}{c}\text { Total contribution to } \\
\text { UK GDP in 2009 }\end{array}$ & $\begin{array}{c}\text { Total contribution to } \\
\text { Exchequer revenues in } \\
2009\end{array}$ & $\begin{array}{c}\text { Employment impact in } \\
2009\end{array}$ \\
\hline $\begin{array}{l}\text { Direct } \\
\text { Multiplier (indirect and }\end{array}$ & $£ 1,594$ million & $£ 445$ million & 36,000 \\
induced plus TV) & $£ 1,714$ million & $£ 425$ million & 36,000 \\
British film box office & $£ 59$ million & $£ 18$ million & \\
effect & $£ 950$ million & $£ 210$ million & 350 \\
Tourism & $£ 20$ million & $£ 5$ million & 20,000 \\
Promotion/trade & $£ 237$ million & $£ 107$ million & 700 \\
Merchandising & $£ 4,574$ million & $£ 1,210$ million & 6,600 \\
Total &
\end{tabular}

Source: The Economic Impact of the UK Film Industry. Independent report published by Oxford Economics in 2012. Commissioned by the BFI and Pinewood Shepperton plc, with support from the British Film Commission and Creative England. 
Figure 1: Production budget distribution

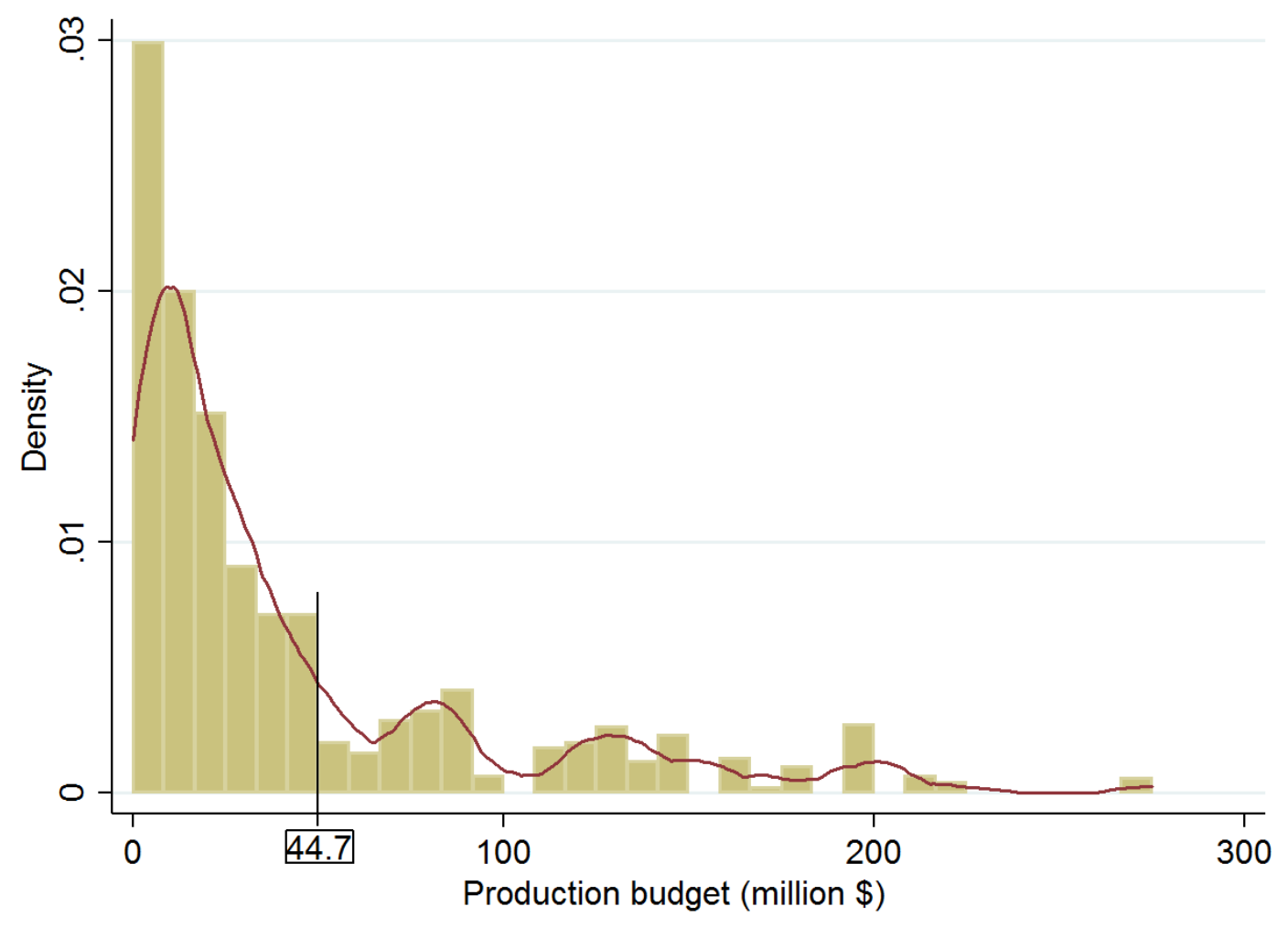


Table 2: Distribution of the length of run

\begin{tabular}{|c|c|c|c|c|c|}
\hline $\begin{array}{l}\text { Length } \\
\text { of Run }\end{array}$ & $\begin{array}{l}\text { Number of } \\
\text { films }\end{array}$ & $\begin{array}{c}\text { Box office } \\
\text { revenues }\end{array}$ & $\begin{array}{l}\text { Advertising } \\
\text { Expenditure }\end{array}$ & $\begin{array}{c}\text { User } \\
\text { Critics }\end{array}$ & $\begin{array}{l}\text { Expert } \\
\text { Critics }\end{array}$ \\
\hline 1 & 552 & 2.76 & 0.50 & 6.63 & 2.92 \\
\hline 2 & 469 & 3.20 & 0.53 & 6.68 & 2.95 \\
\hline 3 & 394 & 3.40 & 0.58 & 6.73 & 2.99 \\
\hline 4 & 323 & 3.63 & 0.62 & 6.75 & 3.01 \\
\hline 5 & 281 & 4.36 & 0.69 & 6.74 & 2.95 \\
\hline 6 & 225 & 4.91 & 0.77 & 6.72 & 2.95 \\
\hline 7 & 185 & 6.07 & 0.84 & 6.73 & 3.00 \\
\hline 8 & 154 & 5.94 & 0.89 & 6.76 & 3.00 \\
\hline 9 & 124 & 7.19 & 0.95 & 6.8 & 3.03 \\
\hline 10 & 104 & 7.86 & 0.99 & 6.88 & 3.07 \\
\hline 11 & 85 & 8.12 & 1.10 & 6.89 & 3.06 \\
\hline 12 & 67 & 9.90 & 1.09 & 6.98 & 3.13 \\
\hline 13 & 51 & 10.70 & 1.06 & 7.2 & 3.29 \\
\hline 14 & 40 & 10.50 & 1.00 & 7.22 & 3.27 \\
\hline 15 & 28 & 11.70 & 1.32 & 7.38 & 3.28 \\
\hline 16 & 21 & 12.20 & 1.23 & 7.39 & 3.36 \\
\hline 17 & 17 & 14.50 & 0.96 & 7.44 & 3.38 \\
\hline 18 & 14 & 13.30 & 1.49 & 7.34 & 3.34 \\
\hline 19 & 10 & 6.97 & 1.22 & 7.33 & 3.50 \\
\hline 20 & 7 & 44.20 & 1.77 & 7.53 & 3.67 \\
\hline 21 & 4 & 6.23 & 1.35 & 8.02 & 4.08 \\
\hline 22 & 4 & 6.44 & 1.35 & 8.02 & 4.08 \\
\hline 23 & 4 & 7.11 & 1.35 & 8.1 & 4.08 \\
\hline 24 & 4 & 7.88 & 1.35 & 8.05 & 4.08 \\
\hline 25 & 3 & 8.95 & 2.14 & 8.1 & 4.23 \\
\hline 26 & 1 & 13.90 & 1.69 & 7.7 & 4.36 \\
\hline 27 & 1 & 14.20 & 1.69 & 7.3 & 4.36 \\
\hline 28 & 1 & 9.10 & 1.69 & 7.8 & 4.36 \\
\hline
\end{tabular}

Note: (1) Box office Revenues and Advertising Expenditure are given in $£$ millions. 
Table 3: Log-rank test for equality of survivor functions

\begin{tabular}{c|cc} 
Budget & Events Observed & Events Expected \\
\hline Low budget & 491 & 379.32 \\
High budget & 61 & 172.68 \\
\hline Total & 552 & 552.00 \\
& Chi2(1) & 114.08 \\
& Pr>Chi2 $=$ & 0.0000
\end{tabular}


Figure 2: Product limit estimator or Kaplan-Meier survival curve

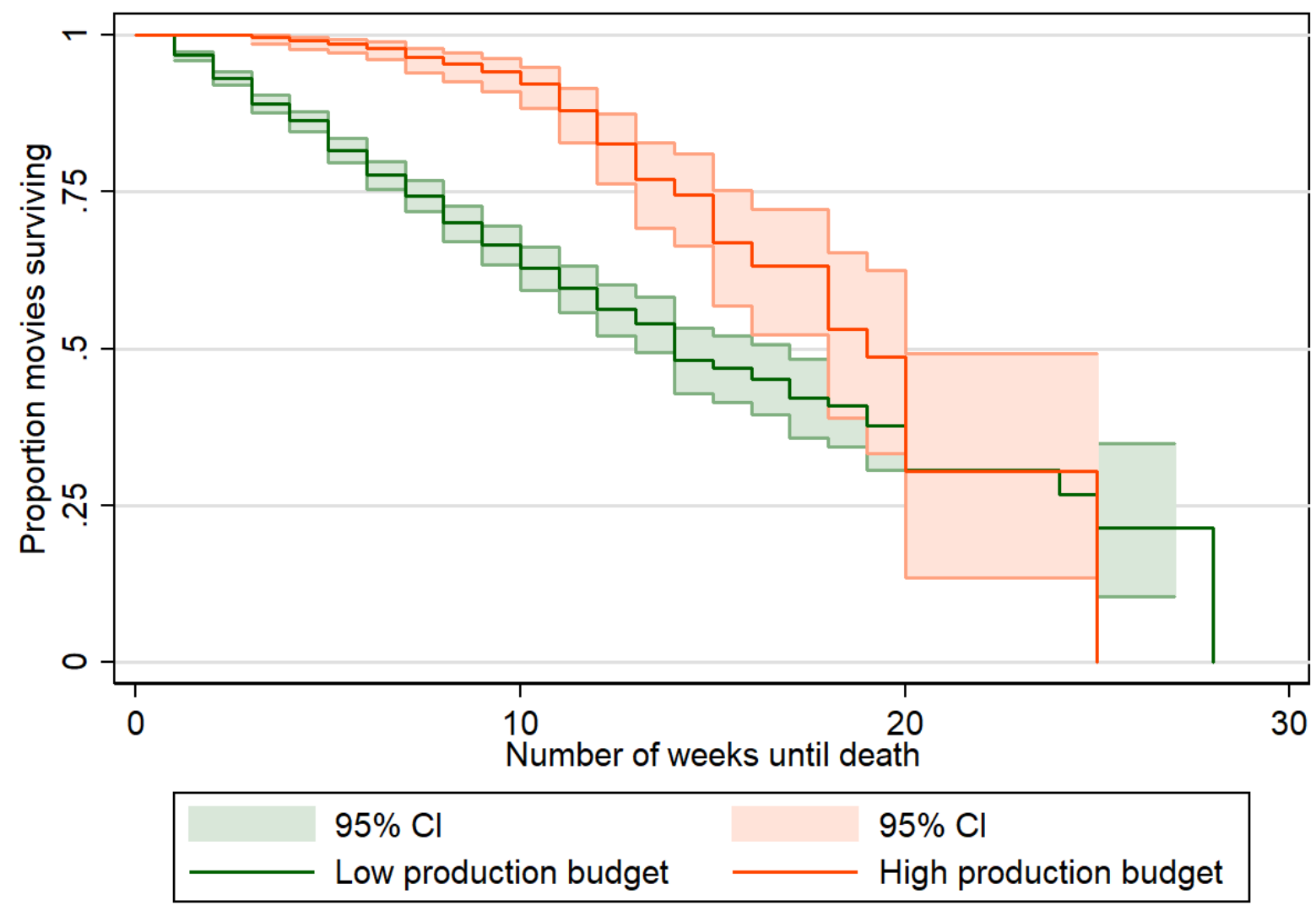


Figure 3: Hazard rate function

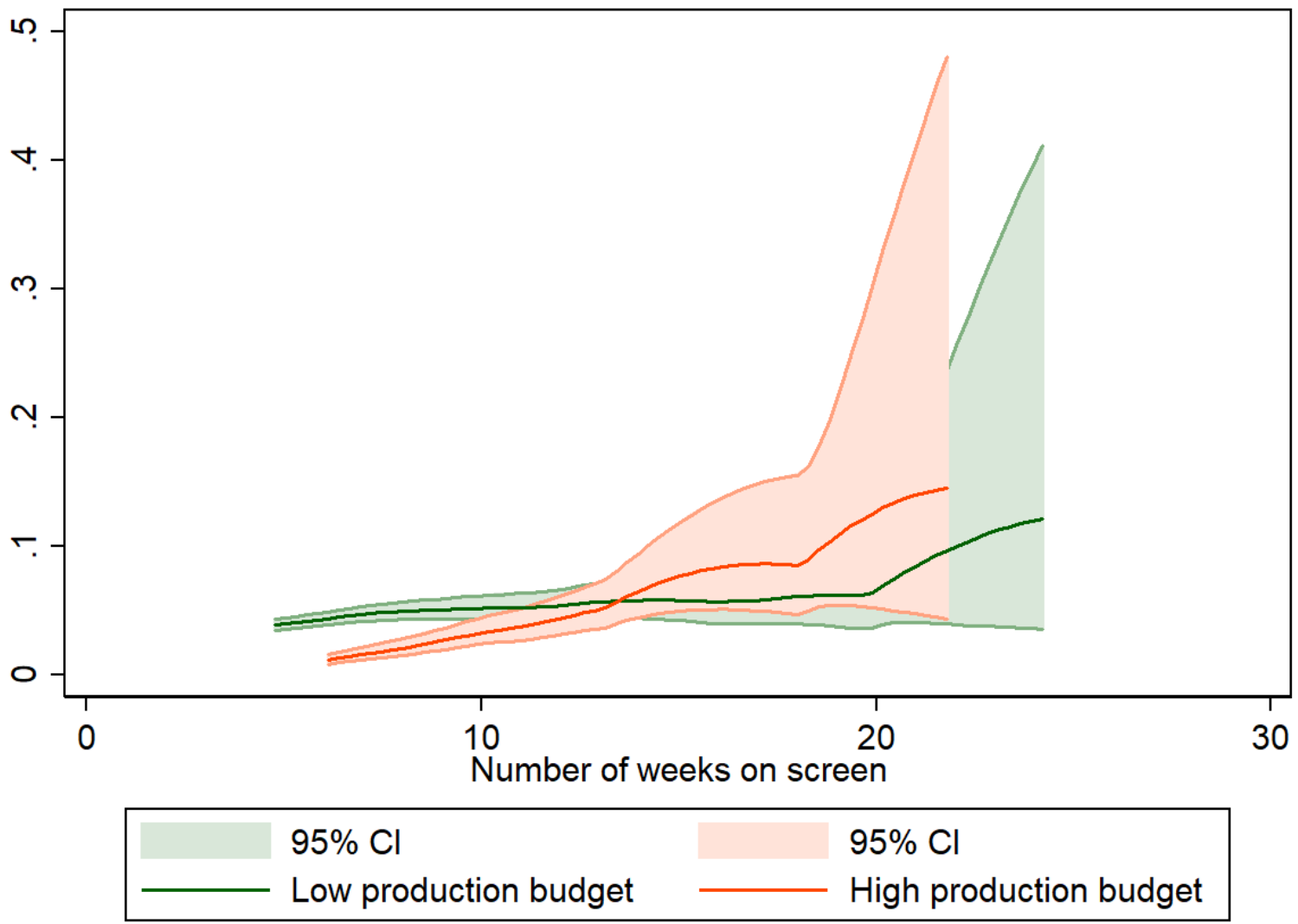


Table 4: clog-log results for low and high budget films

\begin{tabular}{lcccc}
\hline VARIABLES & $(1)$ & $(2)$ & $(3)$ & $(4)$ \\
\hline $\log ($ cross-subsidisation) & $0.0419^{*}$ & $0.0272^{*}$ & -0.0361 & -0.0344 \\
& $(0.0229)$ & $(0.0153)$ & $(0.0361)$ & $(0.0360)$ \\
$\log ($ opportunity cost) & 0.0540 & $0.0889 * * *$ & 0.0710 & 0.0667 \\
& $(0.0370)$ & $(0.0202)$ & $(0.0798)$ & $(0.0779)$ \\
$\log ($ weekly users' votes) & $-0.236^{* * *}$ & $-0.201^{* * *}$ & $-0.206^{* * *}$ & $-0.211^{* * *}$ \\
& $(0.0428)$ & $(0.0319)$ & $(0.0645)$ & $(0.0644)$ \\
Expert critics & $-0.138^{* * *}$ & $-0.103 * * *$ & $-0.232^{* *}$ & $-0.221^{*}$ \\
& $(0.0513)$ & $(0.0343)$ & $(0.114)$ & $(0.113)$ \\
Oscar/BAFTA prizes and nominations & $-1.025^{* * *}$ & $-0.950 * * *$ & -0.467 & -0.459 \\
& $(0.344)$ & $(0.303)$ & $(0.747)$ & $(0.748)$ \\
Popular cast & $-0.421 *$ & $-0.400^{*}$ & 0.356 & 0.411 \\
& $(0.222)$ & $(0.206)$ & $(0.373)$ & $(0.365)$ \\
log(weekly box office revenues) & $-0.237 * * *$ & $-0.290^{* * *}$ & -0.114 & -0.114 \\
& $(0.0569)$ & $(0.0373)$ & $(0.104)$ & $(0.102)$ \\
log(weekly advertising expenditure) & -0.0133 & 0.0164 & $-0.160 * *$ & $-0.156^{*}$ \\
& $(0.0427)$ & $(0.0322)$ & $(0.0812)$ & $(0.0798)$ \\
Book & 0.139 & 0.0830 & -1.320 & -1.393 \\
Sequel & $(0.763)$ & $(0.610)$ & $(1.191)$ & $(1.187)$ \\
& -0.147 & -0.966 & -0.605 & -0.637 \\
Major distributor & $(1.065)$ & $(0.694)$ & $(0.626)$ & $(0.623)$ \\
BBFC under 18 & 0.327 & 0.00803 & -0.138 & -0.136 \\
Seasonal effects & $(0.270)$ & $(0.236)$ & $(0.353)$ & $(0.351)$ \\
Genre dummy variables & -0.342 & -0.208 & -0.592 & -0.530 \\
Production budget proxy & $(0.238)$ & $(0.169)$ & $(0.556)$ & $(0.556)$ \\
Production budget & YES & YES & YES & YES \\
Observations & YES & YES & YES & YES \\
Note: $(1)$ & NO & YES & NO & YES \\
& LOW & LOW & HIGH & HIGH \\
& 1,379 & 2,125 & 680 & 683 \\
\hline
\end{tabular}

Note: (1) *, ** and *** indicate statistical significance at the $10 \%$, the $5 \%$ and the $1 \%$ levels, respectively. Robust standard errors are shown in parentheses. (2) Column 1 and 2 show the results for low budget movies and, column 3 and 4 show the results for high budget movies. 
Table 5: Distribution of the length of run for high and low budget films

\begin{tabular}{|c|c|c|c|c|}
\hline $\begin{array}{l}\text { Length of } \\
\text { Run }\end{array}$ & $\begin{array}{l}\text { Low budget } \\
\text { Films }\end{array}$ & $\begin{array}{l}\text { High budget } \\
\text { Films }\end{array}$ & $\begin{array}{l}\text { Low budget box } \\
\text { office revenues }\end{array}$ & $\begin{array}{l}\text { High budget box } \\
\text { office revenues }\end{array}$ \\
\hline 1 & 491 & 61 & 1.2 & $\begin{array}{ll}11.7 \\
\end{array}$ \\
\hline 2 & 409 & 61 & 1.4 & 10.3 \\
\hline 3 & 334 & 61 & 1.4 & 9.2 \\
\hline 4 & 265 & 59 & 1.9 & 10.8 \\
\hline 5 & 226 & 56 & 1.8 & 9.3 \\
\hline 6 & 172 & 54 & 2.7 & 11.5 \\
\hline 7 & 135 & 51 & 3.1 & 11.8 \\
\hline 8 & 109 & 46 & 3.8 & 11.3 \\
\hline 9 & 82 & 43 & 4.3 & 13.2 \\
\hline 10 & 64 & 40 & 4.5 & 12.3 \\
\hline 11 & 49 & 36 & 6.1 & 13.6 \\
\hline 12 & 38 & 29 & 5.6 & 11 \\
\hline 13 & 29 & 22 & 6.5 & 14.8 \\
\hline 14 & 24 & 16 & 5.4 & 17.2 \\
\hline 15 & 14 & 14 & 11.1 & 16.7 \\
\hline 16 & 12 & 9 & 9.8 & 10.9 \\
\hline 17 & 10 & 7 & 6.3 & 23.3 \\
\hline 18 & 7 & 7 & 6.8 & 16.4 \\
\hline 19 & 6 & 4 & 3 & 10.1 \\
\hline 20 & 4 & 3 & 8.4 & 36 \\
\hline 21 & 3 & 1 & 50.8 & 5.5 \\
\hline 22 & 3 & 1 & 8.2 & 2.4 \\
\hline 23 & 3 & 1 & 74.2 & 5.1 \\
\hline 24 & 3 & 1 & 10.4 & 5.3 \\
\hline 25 & 2 & 1 & 11.1 & 4.9 \\
\hline 26 & 1 & 0 & 14.1 & 0 \\
\hline 27 & 1 & 0 & 14.1 & 0 \\
\hline 28 & 1 & 0 & 14 & 0 \\
\hline
\end{tabular}

Note: (1) Box office revenues are given in $£$ millions (2) Note that high budget films start having higher box office revenues that, in general, gradually decrease over time, however low budget films start having low box office revenues that gradually increase over time. 